\title{
Economic Analysis of Biodiesel and Glycerol Carbonate Production Plant by Glycerolysis
}

\author{
Nghi Nguyen*, Yaşar Demirel \\ Department of Chemical and Biomolecular Engineering, University of Nebraska Lincoln, Lincoln, USA \\ Email: "nghinguyen1985@yahoo.com
}

Received June 12, 2013; revised July 12, 2013; accepted July 30, 2013

Copyright (C) 2013 Nghi Nguyen, Yaşar Demirel. This is an open access article distributed under the Creative Commons Attribution License, which permits unrestricted use, distribution, and reproduction in any medium, provided the original work is properly cited.

\begin{abstract}
Techno-economic analysis of an indirect use of carbon dioxide within the route of glycerolysis of glycerol with urea is investigated. The results show that the net present value of the biodiesel-glycerol carbonate production by glycerolysis is higher than the biodiesel-glycerol carbonate production by direct carboxylationat at the end of the 12-year operation with similar capacities. The stochastic model has predicted that using glycerolysis route for the synthesis of glycerol carbonate production might increase the probability of getting positive net present value by about $15 \%$.
\end{abstract}

Keywords: Biodiesel; Direct Carboxylation; Glycerolysis; Glycerol Carbonate; Economic Analysis

\section{Introduction}

Biodiesel is renewable, nontoxic, biodegradable, and essentially free of sulfur and aromatics, hence it may be one of the most suitable candidates for future biofuel. Besides, US Department of Energy life cycle analysis on biodiesel shows that it produces $78.5 \%$ less net carbon dioxide emissions compared to petroleum diesel [1]. In 2011, the United States produced approximately 1.1 billion gallons of biodiesel and the production is expected to increase to 1.9 billion gallons in 2015 [2]. The major drawbacks of biodiesel production using vegetable oil are the high costs of manufacturing and the feedstock oil, which competes with food. Currently, biodiesel production plants depend on government subsidies in order to keep their plants in operation [2]. Thus, seeking for a more economic biodiesel production process to reduce the dependency of government subsidies and promote expansion of biodiesel industry is desirable.

Recently, a conventional biodiesel production plant was retrofitted using thermodynamic analysis, which employs process heat integration, column grand composite curves, and exergy loss profiles to assess the existing operation and suggest modifications [3]. The retrofit design operates with less thermodynamic imperfections, hence it requires less energy. With a suitable reaction rate, a type of catalyst, relative volatilities of the components, and the reaction and separation temperature range,

${ }^{*}$ Corresponding author. reaction and separation can be combined into a reactive distillation (RD) [4-6]. RD reduces operational and equipment costs by decreasing waste energy and overcoming thermodynamic and chemical equilibrium limitations. Further reduction of energy and equipment cost of the biodiesel production plant is possible by using thermally coupled distillation column sequences as they allow interconnecting vapor and liquid flows between the two columns to eliminate the reboiler or condenser or both [7].

About $1 \mathrm{~kg}$ of glycerol is formed for every $10 \mathrm{~kg}$ of biodiesel produced [8]. The production cost of biodiesel increases by $\$ 0.021 /$ liter for every $\$ 0.22 / \mathrm{kg}$ reduction in glycerol selling price $[9,10]$. As a result, economical utilization schemes of bioglycerol can lead to a more economical biodiesel production plant. A recent study suggests that addition of glycerol carbonate production by direct carboxylation route may be more economical than the conventional biodiesel production plant [11]. However, recently, Li and Wang (2011) [12] have suggested that direct carboxylation of glycerol and $\mathrm{CO}_{2}$ is thermodynamically limited and the yield is very low (less than 35\%) [13]. Low yield requires high energy for the separation of products and the recovery of reactants leading to high cost of manufacturing. Thus, in this study synthesis of glycerol carbonate by glycerolysis route is developed and economics of the biodiesel-glycerol carbonate production by direct carboxylation and glycerolysis plants are compared. Economic analyses based on 
deterministic and stochastic models are used to compare the two plants to determine the most feasible process.

\section{Direct Carboxylation Plant}

The direct carboxylation plant contains two Sections. Section 1 produces biodiesel and crude bioglycerol, while Section 2 produces bioglycerol carbonate and water. Overall, Section 1 consumes $738.89 \mathrm{~kg} / \mathrm{h}$ of methanol and $6419.51 \mathrm{~kg} / \mathrm{h}$ of oil to produce $6482.25 \mathrm{~kg} / \mathrm{h}$ of fatty acid methyl ester (FAME) and $1652.97 \mathrm{~kg} / \mathrm{h}$ of glycerol. The glycerol carbonate production section (Section 2) utilizes $273.74 \mathrm{~kg} / \mathrm{h}$ of carbon dioxide, $266.78 \mathrm{~kg} / \mathrm{h}$ of methanol, and the glycerol as a byproduct of the Section 1 to produce $649.69 \mathrm{~kg} / \mathrm{h}$ of glycerol carbonate and $209.51 \mathrm{~kg} / \mathrm{h}$ of water. Process details are available in reference [11].

\section{Glycerolysis Plant}

\subsection{Glycerolysis Reaction}

Glycerolysis with urea (using urea as $\mathrm{CO}_{2}$ donor) may be described by the following reactions [14].

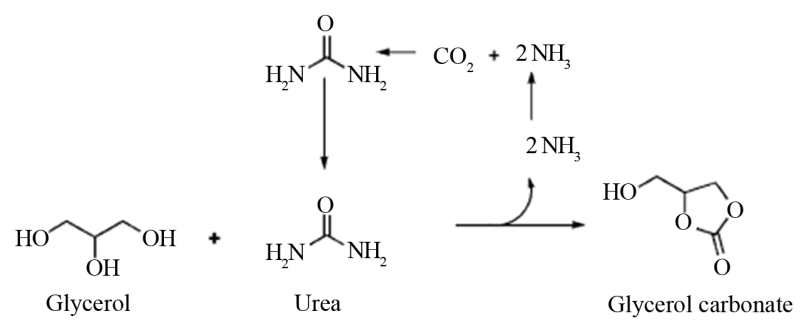

Over $89 \%$ of glycerol carbonate yield with $98.6 \%$ selectivity can be achieved when the reaction proceeds at $140^{\circ} \mathrm{C}, 3 \mathrm{kPa}$, with a glycerol to urea mass ratio of 3.07 , and $1 \%$ of $\mathrm{La}_{2} \mathrm{O}_{3}-600$ as a catalyst in 1 hour. $\mathrm{La}_{2} \mathrm{O}_{3}-600$ shows high stability, even after six consecutive runs and GC yield is still over $84 \%$ with over $97 \%$ selectivity can be obtained [14]. Ammonia $\left(\mathrm{NH}_{3}\right)$ is released when urea reacts with glycerol. Urea can be recovered by reacting $\mathrm{NH}_{3}$ with $\mathrm{CO}_{2}$ under high pressure and temperature [15].

\subsection{Process Flow Diagram}

The glycerolysis plant contains two sections as shown in Figure 1(a). Section 1 (Figure 1(b)) produces biodiesel and crude bioglycerol, while Section 2 (Figure 1(c)) produces bioglycerol carbonate and water. Section 1 utilizes methanol and triglyceride to produce FAME and crude glycerol using calcined eggshell containing mostly $\mathrm{CaO}$ as a catalyst. Utilization of catalyst derived from waste materials reduces the overall cost of manufacturing as well as beneficial to the environment [16]. Recycled and fresh methanol and oil are mixed in mixer M101 and fed into the reactor $\mathrm{R} 101$. When the reaction proceed at $65^{\circ} \mathrm{C}$ and $100 \mathrm{kPa}, 98 \%$ conversion of triglyceride is achieved in 3 hours, with the methanol to oil molar ratio of 9:1 and $3 \%$ of the catalyst [17]. The reactor effluent, stream S2, containing mixture of catalyst, products, and unreacted reactants, is sent to separator SEP101 to recover catalyst, which will be discarded after 13 cycles(approximately 36 hours of operation) [17].

The outlet of separator SEP101, stream S3, enters decanter DEC101 to remove glycerol by phase separation. The top layer, stream S4, of the decanter DEC101 is heated to $104.3^{\circ} \mathrm{C}$ by stream S6 in heater HX101 before it is sent to stage 2 of the distillation column T101. Column T101 operates at 3 stages with a total condenser and a kettle reboiler. The distillate, containing mostly methanol, is recycled while the bottom, containing 6319.55 $\mathrm{kg} / \mathrm{h}$ of FAME, becomes the primary product. The stream properties of the biodiesel plant shown in Figure 1(b) are summarized in Table 1, which is obtained by using the Aspen plus V7.3 with the thermodynamic model of UNIF-DMD. Overall, Section 1 of the glycerolysis plant uses $741.18 \mathrm{~kg} / \mathrm{h}$ of methanol and $6419.51 \mathrm{~kg} / \mathrm{h}$ of oil to produce $6319.55 \mathrm{~kg} / \mathrm{h}$ of FAME and $1653.28 \mathrm{~kg} / \mathrm{h}$ of crude glycerol as summarized in Table 1.

In Section 2, stream BY-PROD is sent to flash drum F201 to recover methanol. Using design specification block, the flow rate of methanol in the distillate of flash drum F201 is set to $30.40 \mathrm{kmol} / \mathrm{h}$ by varying the temperature. Flash drum $\mathrm{F} 201$ operates at $102.44^{\circ} \mathrm{C}$ and 20 $\mathrm{kPa}$. The distillate, stream R5, is recycled to Section 1, while the bottom, stream S1, mixes with the recycled glycerol, stream R4, in Mixer M201. Stream S2, containing mostly glycerol, is heated to reaction conditions before entering reactor R201. Fresh urea, stream UREA, is also sent to reactor R201. The reaction takes place at $140^{\circ} \mathrm{C}$ and $3 \mathrm{kPa}$ with the glycerol to urea mass ratio of 1.79 , and using $1 \%$ of $\mathrm{La}_{2} \mathrm{O}_{3}-600$ as a catalyst in 1 hour. Under these conditions, it was assumed that $85 \%$ yield and $100 \%$ selectivity of glycerol carbonate are achieved [14]. Separator SEP201 is used to recover the catalyst lanthanum oxide from the reactor outlet. After six consecutive runs, lanthanum oxide is discarded as waste [14].

The outlet of separator, stream S5, is cooled to $60^{\circ} \mathrm{C}$ before it is sent to flash drum F202 to separate $\mathrm{NH}_{3}$. Flash drum F202 operates at $60^{\circ} \mathrm{C}$ and $50 \mathrm{kPa}$. Stream $\mathrm{S} 12$ is a secondary by-product containing mostly ammonia and stored after it is cooled to $25^{\circ} \mathrm{C}$. Using additional unit for urea production from $\mathrm{NH}_{3}$ and $\mathrm{CO}_{2}$ is not feasible because of the low production capacity. The bottom product, stream $\mathrm{S} 7$, is heated to $140^{\circ} \mathrm{C}$ in heater $\mathrm{H} 202$ andsent to stage 10 of distillation column T201 to minimize exergy losses caused by the temperature gradient $[3,7,18,19]$. Distillation column T201 operates with 16 equilibrium stages with a partial condenser and a kettle 


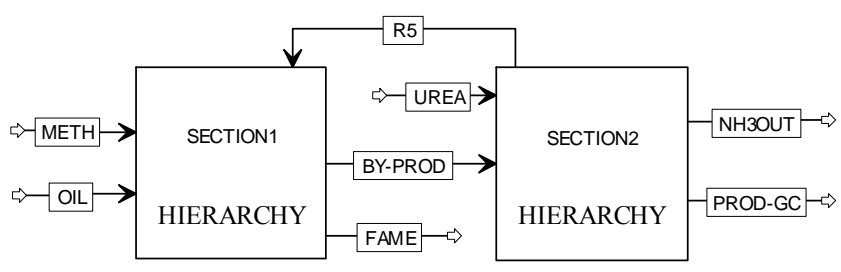

(a)

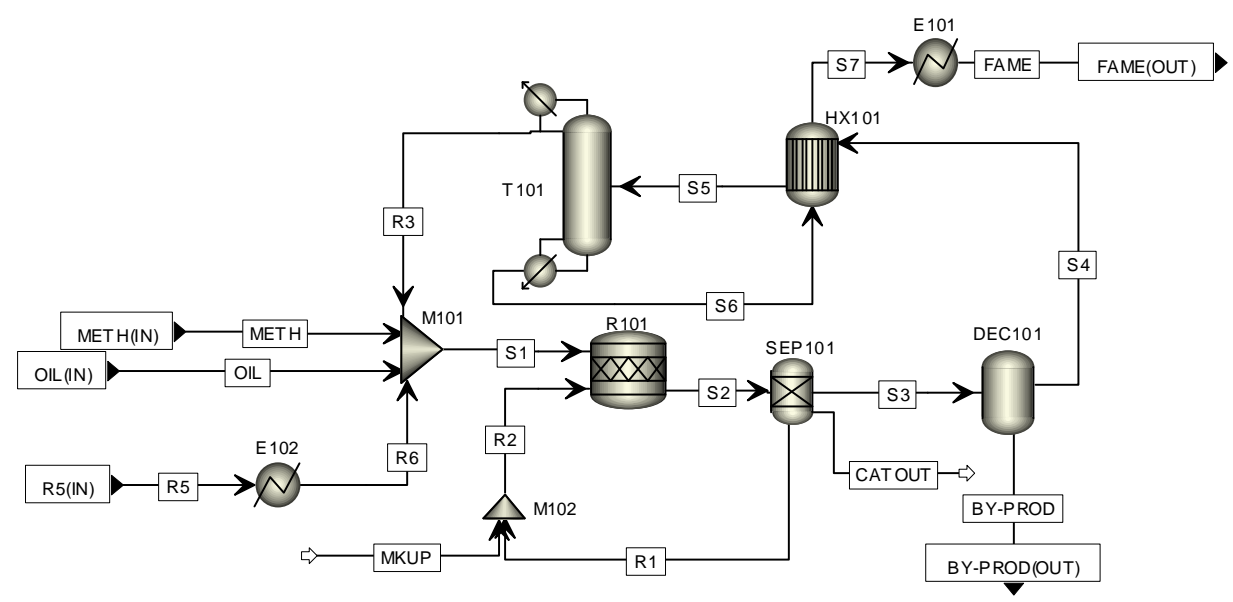

(b)

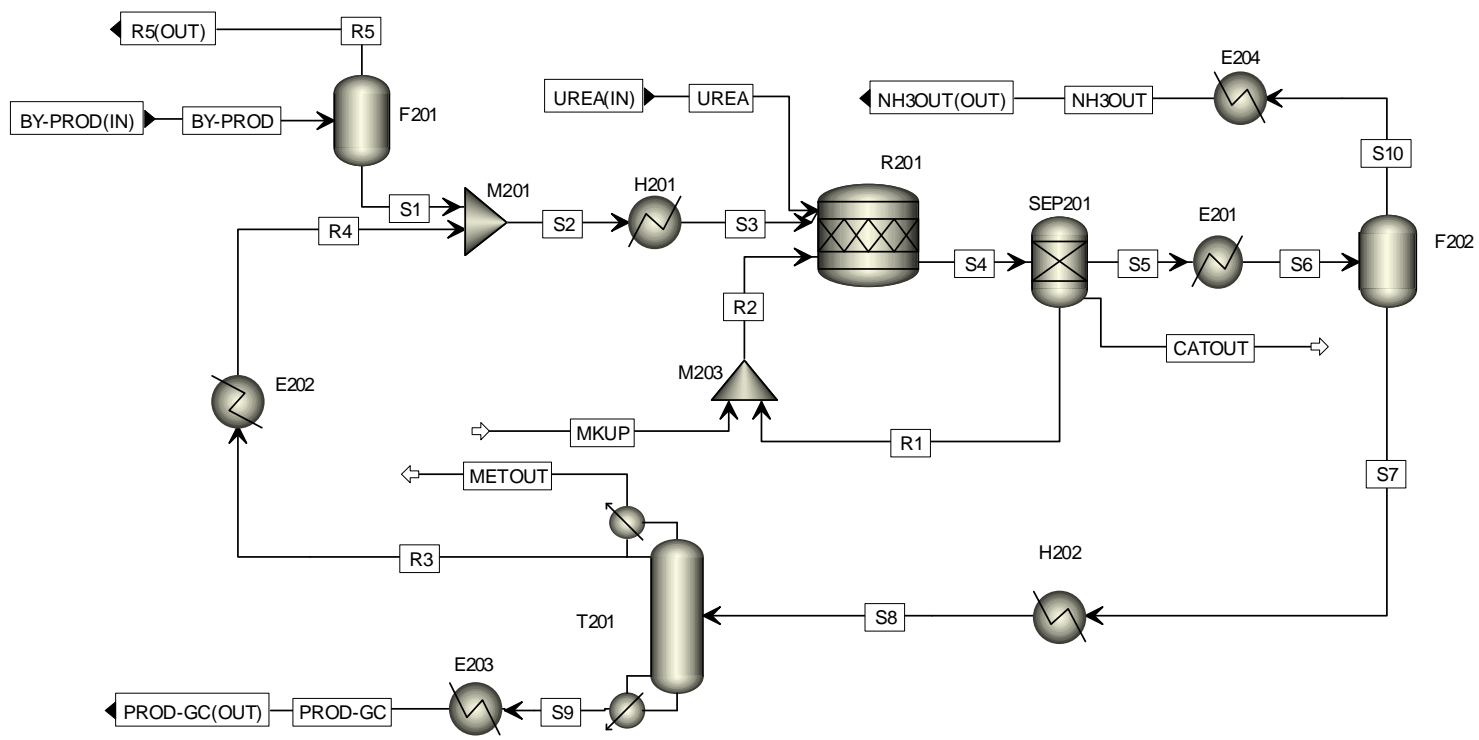

(c)

Figure 1. (a) Hierarchy of the novel biodiesel production plant by glycerolysis route; (b) Process flow diagram of Section 1 for biodiesel and bioglycerol production plant; (c) Process flow diagram of Section 2 for bioglycerol carbonate production plant.

reboiler. Two design specifications are used to control the molar flow rates of methanol and glycerol in the distillate of the distillation column, T201. The first design specification sets the molar flow rate of glycerol in stream R3 to $1 \mathrm{kmol} / \mathrm{h}$ by varying the bottom flow rate. The second design specification sets the flow rate of methanol to $0.065 \mathrm{kmol} / \mathrm{h}$ in stream R3 by varying the distillate vapor fraction. The distillate stream, R3, containing mostly glycerol is recycled. The bottom stream contains $97.59 \%$ of $830.79 \mathrm{~kg} / \mathrm{h}$ of glycerol carbonate as the secondary product as shown in Table 2.

\section{Economic Analysis}

\subsection{Deterministic Model}

The bare module costs of major equipment $C_{B m, i}^{o}$ are estimated using the CAPCOST 2008 program and the chemical engineering plant cost index (CEPCI) of 580 
Table 1. Streams properties of Section 1 of the novel biodiesel production plant by glycerolysis shown in Figure 1(b).

\begin{tabular}{|c|c|c|c|c|c|c|c|c|c|c|c|c|c|}
\hline & BY-PROD & FAME & METH & OIL & R3 & R5 & R6 & S1 & S3 & S4 & S5 & S6 & S7 \\
\hline \multicolumn{14}{|l|}{ Mass Flow $\mathrm{kg} \cdot \mathrm{h}^{-1}$} \\
\hline METHANOL & $9.95 \mathrm{E}+02$ & $3.76 \mathrm{E}+01$ & $7.41 \mathrm{E}+02$ & $0.00 \mathrm{E}+00$ & $3.78 \mathrm{E}+02$ & $9.74 \mathrm{E}+02$ & $9.74 \mathrm{E}+02$ & $2.09 \mathrm{E}+03$ & $1.41 \mathrm{E}+03$ & $4.15 \mathrm{E}+02$ & $4.15 \mathrm{E}+02$ & $3.76 \mathrm{E}+01$ & $3.76 \mathrm{E}+01$ \\
\hline OIL & $1.68 \mathrm{E}-06$ & $1.28 \mathrm{E}+02$ & $0.00 \mathrm{E}+00$ & $6.42 \mathrm{E}+03$ & $1.25 \mathrm{E}-01$ & $1.68 \mathrm{E}-06$ & $1.68 \mathrm{E}-06$ & $66.42 \mathrm{E}+03$ & $1.28 \mathrm{E}+02$ & $1.28 \mathrm{E}+02$ & $1.28 \mathrm{E}+02$ & $1.28 \mathrm{E}+02$ & $1.28 \mathrm{E}+02$ \\
\hline FAME & $3.79 \mathrm{E}+00$ & $6.32 \mathrm{E}+03$ & $0.00 \mathrm{E}+00$ & $0.00 \mathrm{E}+00$ & $7.34 \mathrm{E}-02$ & $3.46 \mathrm{E}+00$ & $3.46 \mathrm{E}+00$ & $3.53 E+00$ & $6.32 \mathrm{E}+03$ & $6.32 \mathrm{E}+03$ & $6.32 \mathrm{E}+03$ & $6.32 \mathrm{E}+03$ & $6.32 \mathrm{E}+03$ \\
\hline GLYCEROL & $6.55 \mathrm{E}+02$ & $2.54 \mathrm{E}+00$ & $0.00 \mathrm{E}+00$ & $0.00 \mathrm{E}+00$ & $4.41 \mathrm{E}-02$ & $2.74 \mathrm{E}+00$ & $2.74 \mathrm{E}+00$ & $2.79 E+00$ & $6.57 \mathrm{E}+02$ & $2.59 \mathrm{E}+00$ & $2.59 \mathrm{E}+00$ & $2.54 \mathrm{E}+00$ & $2.54 \mathrm{E}+00$ \\
\hline \multicolumn{14}{|l|}{ Mass Frac } \\
\hline METHANOL & 0.6018 & 0.0058 & 1.0000 & 0.0000 & 0.9994 & 0.9937 & 0.9937 & 0.2457 & 0.1655 & 0.0605 & 0.0605 & 0.0058 & 0.0058 \\
\hline OIL & 0.0000 & 0.0198 & 0.0000 & 1.0000 & 0.0003 & 0.0000 & 0.0000 & 0.7535 & 0.0151 & 0.0187 & 0.0187 & 0.0198 & 0.0198 \\
\hline FAME & 0.0023 & 0.9740 & 0.0000 & 0.0000 & 0.0002 & 0.0035 & 0.0035 & 0.0004 & 0.7423 & 0.9204 & 0.9204 & 0.9740 & 0.9740 \\
\hline GLYCEROL & 0.3959 & 0.0004 & 0.0000 & 0.0000 & 0.0001 & 0.0028 & 0.0028 & 0.0003 & 0.0771 & 0.0004 & 0.0004 & 0.0004 & 0.0004 \\
\hline Total Flow $\mathrm{kg} \cdot \mathrm{h}^{-1}$ & 1653.28 & 6487.93 & 741.18 & 6419.51 & 377.99 & 980.52 & 980.52 & 8519.20 & 8519.20 & 6865.92 & 6865.92 & 6487.93 & 6487.93 \\
\hline Temperature ${ }^{\circ} \mathrm{C}$ & 65.00 & 25.00 & 25.00 & 25.00 & 64.31 & 100.00 & 25.00 & 25.09 & 65.00 & 65.00 & 104.30 & 138.37 & 75.00 \\
\hline Pressure kPa & 100 & 100 & 100 & 100 & 100 & 20 & 100 & 100 & 100 & 100 & 100 & 100 & 100 \\
\hline
\end{tabular}

for the year 2011 [20]. The Fixed Capital Investment (FCI) of the direct carboxylation plant is $\$ 29,276,352$, while the FCI of the glycerolysis plant is $\$ 27,000,160$ as shown in Table 3. The cost estimation accuracies of the preliminary designs range from $+25 \%$ to $-15 \%$ of the actual costs. Land (L) and working capital (WC) are assumed equal to $5 \%$ and $20 \%$ of FCI, respectively. Table 3 also shows the total cost of utilities. The costs of utilities for low and medium pressure steam, cooling water, and electricity [21] are updated using the 2011 CEPCI of 580 . Number of employee $\left(N_{O L}\right)$ is estimated using equation from reference [22]. All the costs can be updated by using the current value of CEPCI in Cost(new) = Cost(old)[CEPCI(new)/CEPCI(old)].

The total cost of labor summarized in Table 3 is calculated based on $8400 \mathrm{~h} /$ year of the plant operation. The cost of waste disposal is $\$ 0.37 / \mathrm{kg}$ [21]. The price of oil and methanol are $\$ 0.79 /$ Liter and $\$ 0.20 /$ Liter, respecttively. The current selling price of products is presented in Table 3. With the inclusion of tax incentive and renewable index number, biodiesel producers can get up to $\$ 0.74 /$ Liter in addition to the market price of biodiesel [23], making the selling price of biodiesel approximately equal to $\$ 1.19 /$ Liter. Salvage (S) value is $5 \%$ of FCI [22]. The useful life of the plants, taxation rate $(t)$, years of depreciation and interest rate are also presented in Table 3. In the deterministic model, based on the most likely economic data considered in Table 3, discounted cash flows (DCF) and cumulative discounted cash flows (CDCFs) are estimated. The plot of DCFs versus years of operation yields the feasibility criteria of net present value (NPV), payback period (PBP), and rate of return (ROR). For a feasible operation, at least two criteria must satisfy the conditions: NPV $\geq 0$; ROR $>i$ (interest rate), and $\mathrm{PBP} \geq n$ (plant operation time).

\subsection{Stochastic Model}

In reality, parameters used to evaluate profitability are subject to change throughout the life of the chemical plant. Stochastic model incorporates Monte-Carlo simulation into economic analysis to quantify the uncertainty on the values of NPV, PBP, and ROR [22]. Trapezoidal, normal, and lognormal density cumulative probability density function are often used to describe uncertainty in data. However, triangular cumulative probability function $(P(x))$ can be used to reduce calculation complexity [22]

$$
\begin{gathered}
P(x)=\frac{(x-a)^{2}}{(c-a)(b-a)} \text { for } x \leq b \\
P(x)=\frac{(b-a)}{(c-a)}+\frac{(x-b)(2 c-x-b)}{(c-a)(c-b)} \text { for } x>b
\end{gathered}
$$

where $a$ is the estimate of the lowest value, $b$ is the most likely value and $c$ is the estimate of the highest value. The uncertainties on the fixed capital investment, price of product, working capital, income tax rate, interest rate, raw material, and salvage values are considered for stochastic model economic comparison. The assumed uncertainties of those parameters from the base value are listed in Table 4.

\section{Results and Discussions}

The market value of crude bioglycerol is low due to its 


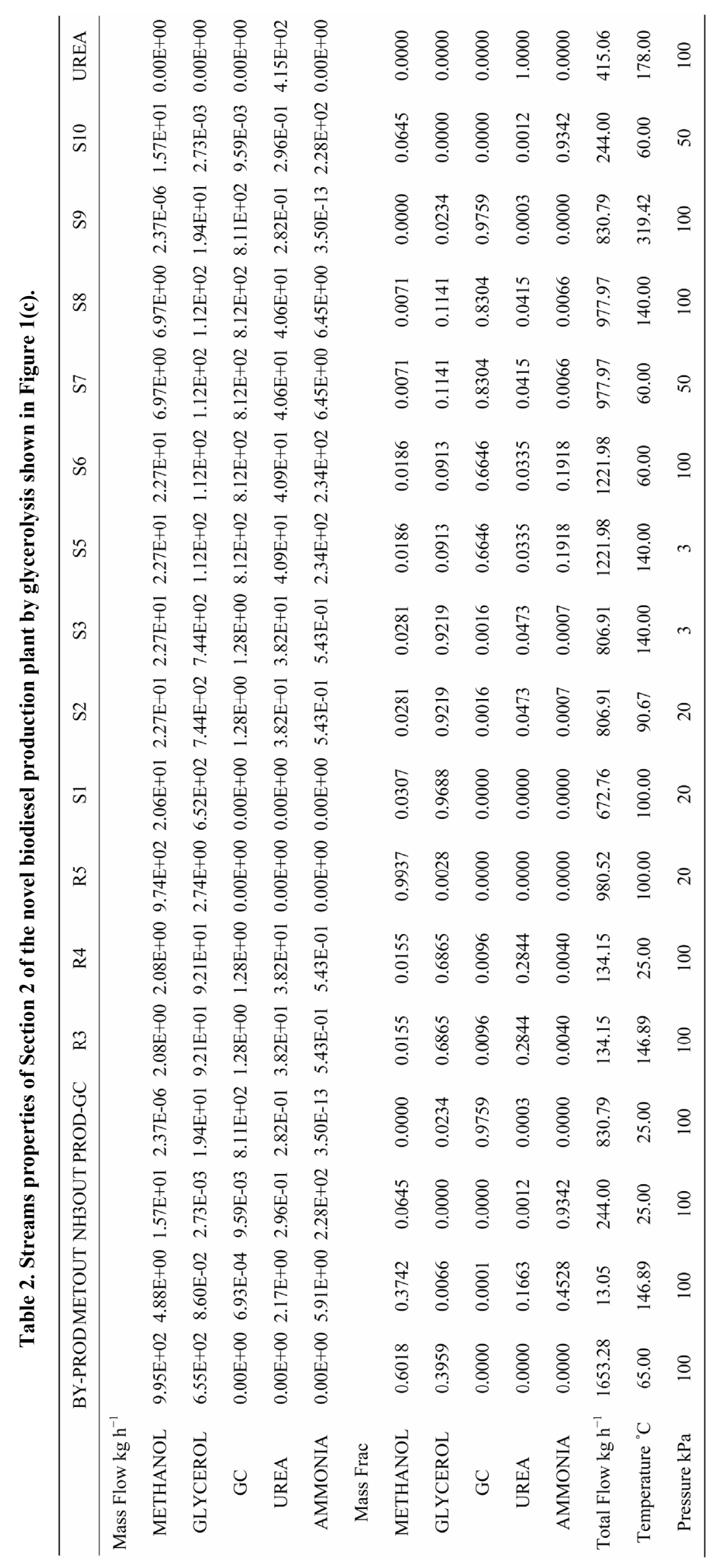


Table 3. Major cost factors of the biodiesel with glycerol carbonate production plants.

\begin{tabular}{|c|c|c|}
\hline & $\begin{array}{c}\text { Direct } \\
\text { Carbonxylation }\end{array}$ & Glycerolysis \\
\hline Fixed capital investment $(\mathrm{FCI}), \$$ & $29,276,352.00$ & $27,000,160.00$ \\
\hline Land (L), $\$(5 \%$ of FCI) & $1,463,817.60$ & $1,350,008.00$ \\
\hline $\begin{array}{l}\text { Working capital (WC), } \\
\qquad \begin{array}{l}(20 \% \text { of FCI })\end{array}\end{array}$ & $5,855,270.40$ & $5,400,032.00$ \\
\hline Labor, $\$ \mathrm{~h}^{-1}$ & 30 & 30 \\
\hline Operating labor & 16 & 16 \\
\hline Cost of labor (COL), $\$$ & $4,032,000.00$ & $4,032,000.00$ \\
\hline Cost of Electricity, $\$ \mathrm{~kW}^{-1} \cdot \mathrm{h}^{-1}$ & 0.0666 & 0.0666 \\
\hline Cost of cooling water, $\$$ tonne ${ }^{-1}$ & 0.0202 & 0.0202 \\
\hline Cost of 1 bar steam, $\$$ tonne $^{-1}$ & 2.4 & 2.4 \\
\hline Cost of 22 bar steam, $\$$ tonne ${ }^{-1}$ & - & 14.7 \\
\hline Cost of 35 bar steam, $\$$ tonne $^{-1}$ & 16.6 & - \\
\hline Cost of 190 bar steam, $\$$ tonne $^{-1}$ & - & 23.3 \\
\hline Cost of utilities (CUT), \$ & $982,856.23$ & $347,810.85$ \\
\hline Waste treatment, $\$ \mathrm{~kg}^{-1}$ & 0.37 & 0.37 \\
\hline Waste treatment (S), \$ & $987,610.17$ & $124,596.33$ \\
\hline Cost of methanol, $\$ \mathrm{~L}^{-1}$ & 0.20 & 0.20 \\
\hline Cost of oil, $\$ \mathrm{~L}^{-1}$ & 0.79 & 0.79 \\
\hline Cost of $\mathrm{CO}_{2}, \$ \mathrm{~kg}^{-1}$ & 0.045 & 0.045 \\
\hline Cost of Urea, $\$ \mathrm{~kg}^{-1}$ & - & 0.27 \\
\hline Cost of $\mathrm{CaO}, \$ \mathrm{~kg}^{-1}$ & 0.10 & 0.10 \\
\hline Cost of $\mathrm{n}-\mathrm{Bu}_{2} \mathrm{SnO}, \$ \mathrm{~kg}^{-1}$ & 17.15 & - \\
\hline Cost of $\mathrm{La}_{2} \mathrm{O}_{3}, \$ \mathrm{~kg}^{-1}$ & - & 12.00 \\
\hline Total cost of raw materials, $\$$ & $48,752,136.47$ & $49,590,018.45$ \\
\hline Cost of manufacturing $(\mathrm{COM}), \$$ & $78,665,904.89$ & $77,444,172.33$ \\
\hline Price of FAME, $\$ \mathrm{~L}^{-1}$ & 1.19 & 1.19 \\
\hline Price of GC, $\$ \mathrm{~kg}^{-1}$ & 2.4 & 2.4 \\
\hline Price of $\mathrm{NH}_{3}, \$ \mathrm{~kg}^{-1}$ & - & 0.12 \\
\hline Revenue (R), $\$$ yr $^{-1}$ & $88,881,165.58$ & $92,393,726.54$ \\
\hline Salvage value (S), \$ & $1,463,817.60$ & $1,350,008.00$ \\
\hline Taxation rate $(\mathrm{t}), \%$ & 35 & 35 \\
\hline Years of operation (n) & 12 & 12 \\
\hline Years of depreciation $^{* *}(\mathrm{k})$ & 5 & 5 \\
\hline Operational time, $\mathrm{h} \mathrm{yr}^{-1}$ & 8400 & 8400 \\
\hline Interest rate (i), \% & 5 & 5 \\
\hline
\end{tabular}

L: Liter; ${ }^{* *}$ Depreciation method: Modified Accelerated Cost Recovery System (MACRS). excess production as a by-product of the biodiesel production. Purification of glycerol in a small to medium scale biodiesel production plant is not feasible due to high investment in separation units and low ROR.

Figure 2 shows the discounted cash flow diagrams generated using the deterministic model based on the 5 year Modified Accelerated Cost Recovery System (MACRS) depreciation method. Table 5 presents the discounted profitability criteria of the two plants. Any two criteria should be favorable for the project to be feasible. The net present value of the glycerolysis plant is about \$27.83million higher than the direct carboxylation plant at the end of 12-year project. The discounted payback period of the direct carboxylation and glycerolysis plants is 3.7 and 2.4 years, respectively, as shown in Table 5 .

Table 4. Uncertainties on some key economic parameters.

\begin{tabular}{ccc}
\hline & Lower Limit (a) & Upper Limit (c) \\
\hline Fixed capital investment & $-20 \%$ & $30 \%$ \\
Price of product & $-10 \%$ & $10 \%$ \\
Working capital & $-30 \%$ & $10 \%$ \\
Income tax rate & $-20 \%$ & $20 \%$ \\
Interest rate & $-10 \%$ & $20 \%$ \\
Raw material price & $-10 \%$ & $15 \%$ \\
Salvage value & $-30 \%$ & $20 \%$ \\
\hline
\end{tabular}

Table 5. Discounted profitability criteria.

\begin{tabular}{ccc}
\hline & $\begin{array}{c}\text { Direct } \\
\text { Carboxylation }\end{array}$ & Glycerolysis \\
\hline $\begin{array}{c}\text { Net Present Value } \\
\text { (millions) }(\mathrm{NPV} \geq 0)\end{array}$ & 34.05 & 61.88 \\
$\begin{array}{c}\text { Discounted Cash Flow } \\
\text { Rate of Return (ROR }>i) \\
\quad \text { Discounted Payback }\end{array}$ & $19.91 \%$ & $32.08 \%$ \\
Period (years) (DPBP $\geq n)$ & 3.7 & 2.4 \\
\hline
\end{tabular}

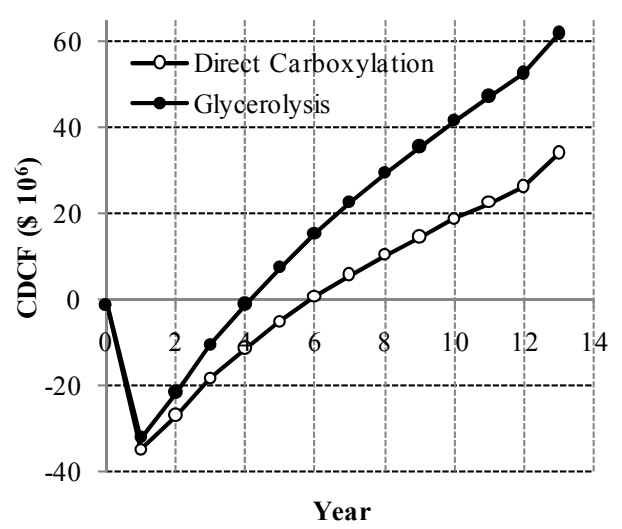

Figure 2. Comparison of the cumulative discounted cash flow (CDCF) diagrams of the direct carboxylation and glycerolysis routes. 
Table 4 presents the uncertainties on some of the key parameters over the plant life. Figure 3 presents the cumulative probability distributions obtained 1000-point Monte Carlo simulations for the values of NPV, discounted cash flow rate of return (DCFROR) and discounted payback period (DPBP) obtained using CAPCOST 2008 software based on the uncertainties of parameters shown in Table 4 [20]. Figure 3(a) shows that

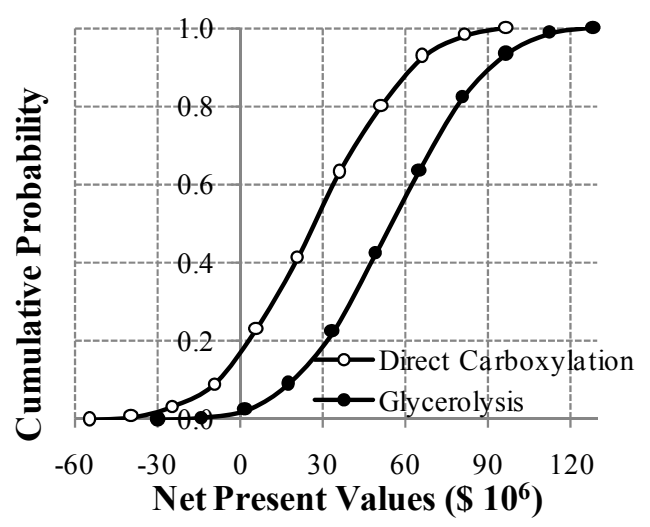

(a)

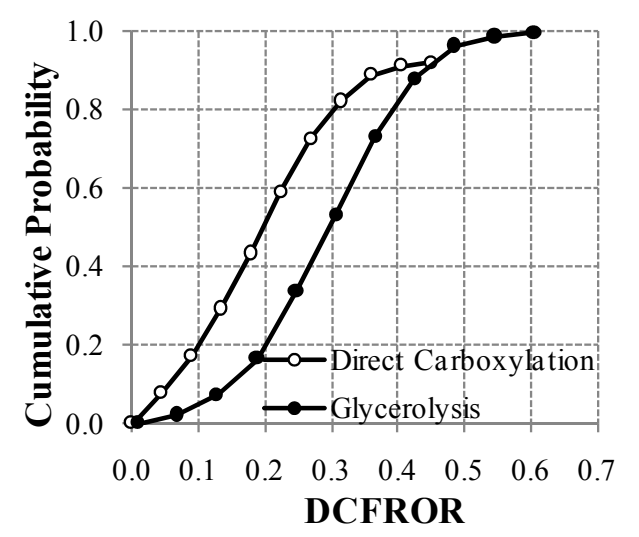

(b)

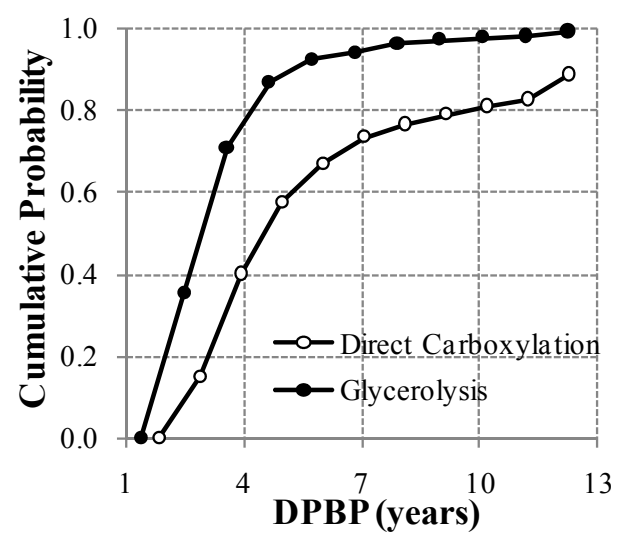

(c)

Figure 3. 1000-point Monte Carlo simulation on; (a) Net present values (NPV); (b) Discounted cash flow rate of return (DCFROR); (c) Discounted payback period (DPBP). there is about $17 \%$ chance that the direct carboxylation plant will not be profitable, while there is approximately $2 \%$ chance that the glycerolysis plant will not be profitable. The glycerolysis plant is about $15 \%$ more likely to be profitable compared to the direct carboxylation plant. If the median probability of $50 \%$ is considered, the glycerolysis plant yields a higher value of NPV of \$28million. The lowest values of NPV for the direct carboxylation and glycerolysis plants are $-\$ 63.8$ and $-\$ 29.5$ million, respectively, while the highest possible values of NPV for the direct carboxylationand glycerolysis plants are $\$ 151.5$ and $\$ 128.2$ million, respectively.

\section{Conclusion}

Production of glycerol carbonate using direct carboxylation route suffers from low yield and costly separation units. In contrast, the glycerolysis route using $\mathrm{CO}_{2}$ indirectly and urea as a $\mathrm{CO}_{2}$ donor may simplify the glycerol carbonate production, and hence it leads to a more economical biodiesel-glycerol carbonate production process. Deterministic model predictions show that the net present value of the glycerolysis plant is higher than that of the direct carboxylation plant at the end of 12-year operation. Stochastic model for the economic analysis predicts that the glycerolysis route for glycerol carbonate production increases the probability of getting positive net present value by about $15 \%$.

\section{REFERENCES}

[1] J. Sheehan, V. Camobreco, J. Duffield, M. Graboski and H. Shapouri, "Life Cycle Inventory of Biodiesel and Petroleum Diesel for Use in an Urban Bus [Internet],"NREL, 2011. http://www.nrel.gov/docs/legosti/fy98/24089.pdf

[2] J. M. Urbanchuk, "Economic Impact of Removing the Biodiesel Tax Credit for 2010 and Implementation of RFS2 Targets through 2015 [Internet]," Cardno ENTRIX, 2012.

http://www.biodiesel.org/reports/20110608_gen-425.pdf

[3] N. Nguyen and Y. Demirel, "Retrofit of Distillation Columns in Biodiesel Production Plants," Energy, Vol. 35, No. 4, 2010, pp. 1625-1632. doi:10.1016/j.energy.2009.12.009

[4] A. C. Dimian, C. S. Bildea and F. Omota, "Innovative Process for Fatty Acid Esters by Dual Reactive Distillation," Computers \& Chemical Engineering, Vol. 33, No. 3, 2009, pp. 743-750. doi:10.1016/j.compchemeng.2008.09.020

[5] W. L. Luyben and C.-C. Yu, "Reactive Distillation Design and Control," Wiley, New York, 2008.

[6] N. Nguyen and Y. Demirel, "Reactive Distillation Column for Esterification of Lauric Acid with Methanol: Equilibrium vs. Nonequilibrium Approaches," American Institute of Chemical Engineers Annual Meeting Conference Proceedings, Salt Lake City, 2010.

https://aiche.confex.com/aiche/2010/webprogram/Paper1 
97994.html

[7] N. Nguyen and Y. Demirel, "Using Thermally Coupled Reactive Distillation Columns in Biodiesel Production," Energy, Vol. 36. No. 8, 2011, pp. 4838-4847. doi:10.1016/j.energy.2011.05.020

[8] N. Nguyen and Y. Demirel, "Carboxylation of Glycerol in a Biodiesel Plant," American Institute of Chemical Engineers Annual Meeting Conference Proceedings, Salt Lake City, 2010.

http://www3.aiche.org/Proceedings/Abstract.aspx?PaperI $\mathrm{D}=197821$

[9] S. Behzadi and M. M. Farid, "Review: Examining the Use of Different Feedstock for the Production of Biodiesel," Asia-Pacific Journal of Chemical Engineering, Vol. 2, No. 5, 2007, pp. 480-486.

[10] Y. Zheng, X. Chen and Y. Shen, "Commodity Chemicals Derived from Glycerol, an Important Biorefinery Feedstock," Chemical Reviews, Vol. 108, No. 12, 2008, pp. 5253-5277. doi:10.1021/cr068216s

[11] N. Nguyen and Y. Demirel, "A novel Biodiesel and Glycerol Carbonate Production Plant," International Journal of Chemical Reactor Engineering, Vol. 9, No. 1, 2011, p. A108. doi:10.2202/1542-6580.2856

[12] J. Li and T. Wang, "Chemical Equilibrium of Glycerol Carbonate Synthesis from Glycerol," The Journal of Chemical Thermodynamics, Vol. 43, No. 5, 2011, pp. 731736. doi:10.1016/j.jct.2010.12.013

[13] J. George, Y. Patel, S. Pillai and P. Munshi, "Methanol Assisted Selective Formation of 1,2-Glycerol Carbonate from Glycerol and Carbon Dioxide Using ${ }^{n} \mathrm{Bu}_{2} \mathrm{SnO}$ as a Catalyst," Journal of Molecular Catalysis A: Chemical, Vol. 304, No.1-2, 2009, pp. 1-7. doi:10.1016/j.molcata.2009.01.010

[14] L. Wang, Y. Ma, Y. Wang, S. Liu and Y. Deng, "Efficient Synthesis of Glycerol Carbonate from Glycerol and Urea with Lanthanum Oxide as a Solid Base Catalyst," Catalysis Communications, Vol. 12, No. 15, 2011, pp. 1459-1462. doi:10.1016/j.catcom.2011.05.027
[15] K. Piotrowski, J. Piotrowski and J. Schlesinger, "Modeling of Complex Liquid-Vapour Equilibria in the Urea Synthesis Process with the Use of Artificial Neural Network," Chemical Engineering and Processing, Vol. 42, No. 4, 2003, pp. 285-289. doi:10.1016/S0255-2701(02)00060-0

[16] R. Chakraborty, S. Bepari and A. Banerjee, "Transesterification of Soybean Oil Catalyzed by Fly Ash and Egg Shell Derived Solid Catalysts," Chemical Engineering Journal, Vol. 165, No. 3, 2010, pp. 798-805. doi:10.1016/i.cej.2010.10.019

[17] Z. Wei, C. Xu and B. Li, "Application of Waste Eggshell as Low-Cost Solid Catalyst for Biodiesel Production," Bioresource Technology, Vol. 100, No. 11, 2009, pp. 2883-2885. doi:10.1016/j.biortech.2008.12.039

[18] S. Bandyopadhyay, R. K. Malik and U. V. Shenoy, "Temperature-Enthalpy Curve for Energy Targeting of Distillation Columns," Computers \& Chemical Engineering, Vol. 22, No. 12, 1998, pp. 1733-1744. doi:10.1016/S0098-1354(98)00250-6

[19] Y. Demirel, "Retrofit of Distillation Columns Using Thermodynamic Analysis," Separation Science and Technology, Vol. 41, No. 5, 2006, pp. 791-817. doi:10.1080/01496390600600047

[20] Y. Feng and G. P. Rangaiah, "Evaluating Capital Cost Estimation Programs [Internet]," National University of Singapore, Singapore City, 2011. http://www.che.com/technical and practical/8359.html

[21] W. D. Seider, J. D. Seader and D. R. Lewin, "Product and Process Design Principles," 3rd Edition, John Wiley \& Sons, Inc., Hoboken, 2009.

[22] R. Turton, R. C. Bailie and W. B. Whiting, "Analysis, synthesis, and Design of Chemical Processes," 3rd Edition, Prentice Hall, Upper Saddle River, 2008.

[23] L. Geiver, "Biodiesel RIN Prices Reach New Highs, Could Be Headed Higher [Internet]," Biodiesel Magazine, 2012. http://www.biodieselmagazine.com/articles/7611/biodiesel-rin-prices-reach-new-highs-could-be-headed-higher 